\title{
Integration of citizenship education with religious education in Lesotho secondary schools
}

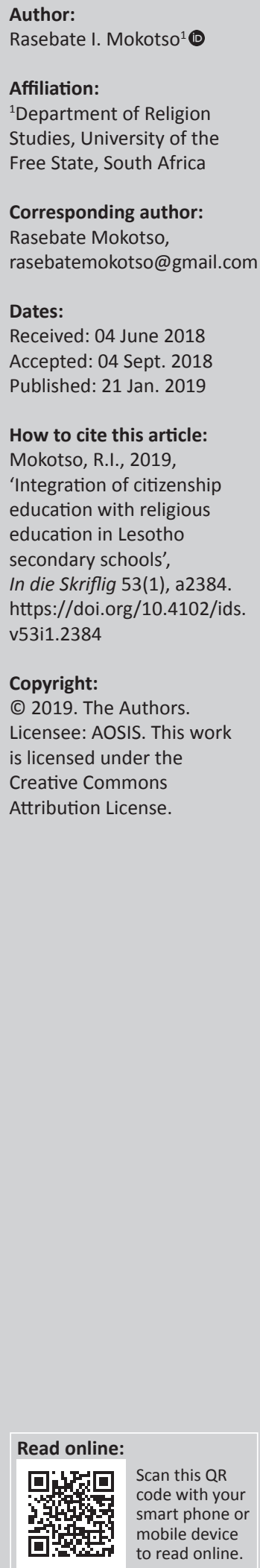

The current article fervently acknowledges the general agreement that Lesotho had never experienced a stable democracy ever since the ultimate attainment of political independence in 1966. Among other possible solutions proposed to the problem of Lesotho's democratic instability, citizenship education dominates government documents and various works regarding the political discourse. Although there is this pervasive recognition of the needed political educational intervention, there is no explicit direction on how to properly introduce the envisaged citizenship education. The article valiantly attempts bridging this visible gap by carefully probing the published literature to propose the meaningful integration of citizenship education with religious education. The discussion was guided by the critical use of the postsecular theoretical framework. The article highlights that, coupled with post-Christianity, post-secular theory undoubtedly provided a workable framework for the meaningful integration of secular (political citizenship) and religious essences for the promotion of democratic stability in Lesotho. The article logically concludes by showing that the proposed integration of citizenship education in religious education is within acceptable philosophical modes of proper education.

\section{Introduction}

There is sufficiently prevailing consensus that Lesotho has never experienced a stable democracy ever since political independence. Right from the first democratic elections of 1965, which instated the Basotho National Party (BNP) as the governing party, the mountain kingdom experienced extreme enfeeblement democracy that is marked by continuous post elections conflicts with series of army coups. To cite some notable approving examples, Makoa (2004:79) neatly assembles conclusive evidence to show that Lesotho did not experience a stable democracy ever since independence. There was merely a short-lived intermediary stability of 1966 to 1970 and 1993 to 2003. Motsamai (2015:2) also approves an essential idea that violence and political power struggle fiercely besmeared Lesotho politics right from the onset of political independence in 1966 to the present. In the same vein, Vhumbunu (2015:4) assuredly concurs that since independence Lesotho endured a continuous history of political instability characterised by factionalism, tensions, and violent conflicts. Political violence persistently engulfs the country more particularly, during and after general elections. On the same subject, Monyane (2009:1) earnestly affirms that it is precisely over 50 prime years of Lesotho's self-governing period without stable democracy. By contrast, there have been continuous instability and turbulent periodic political violence. In notable addition, Akokpari (1998:66) augments that insubstantiality labelled Lesotho's post-independence democracy ever since the first democratic elections. These are few of many examples backing the noticeable absence of a meaningful democracy in Lesotho from the inception of political independence from the colonial rule. Indisputably, there are different causes and possible solutions suggested. However, many of the recommended solutions, focus more on political processes, institutions, and structures as well as economic adjustments (Bertelsmann Stiftung's Transformation Index BTI 2016:42; Makoa 2004:92-93; Motsamai 2015:12-13). The intention of this conceptual article is to shift the focus from the exclusive emphasis on a political solution. It proposes a pedagogical strategy that appropriately integrates religious knowledge and democratic citizenship.

There are invariably some leading analysts and official government documents suggesting the imperative necessity of introducing citizenship education as the essential strategy for Lesotho's democratic consolidation. On their part, Tsikoane et al. $(2007: 32,78,81)$ reasonably argue that there could be no meaningful stable democracy without the participation of all citizens in politically related issues and activities. Only politically informed citizens could effectively participate in the political decisions and processes beyond the ballot box. They therefore sternly 
recommend citizenship education as a measurable cardinal tactic empowering all citizens and to enable them to hold the government accountable on democratic values. Gay and Green (2005:24) noticed that all Basotho, including politicians and ordinary citizens, do not vigorously support democratic values. Ordinary Basotho in particular, undeniably continue to demonstrate a modest level of civic participation in politics. They are also hesitant to act against possible violations of democratic principles by political authorities. Gay and Green (2005:25) fittingly concluded their analysis by enthusiastically endorsing inclusive civic education. In their view, civic education can provide the citizens with knowledge on the democratic rule and empower them to participate in democratic decision making. In support, the government document, National Strategic Development Plan 2012/13-2016/17, strongly recommends the introduction of a vigorous civic education program in schools, beginning from as early as the lower primary levels. This kind of education must act as a pertinent strategy to foster values of democracy to counteract constant threats to political stability. The document emphasises that civic education can meaningfully cultivate the political capacity for peaceful conflict resolution and possibly promote social cohesion (International Monetary Fund 2012:149-159). Another government document, Poverty Reduction Strategy 2004/2005-2005/2007, considers the political unrest of 1998 which caused extensive damage to the country's economy as a visible indication that without national unity and political stability, the country cannot progress economically, or be able to address the current rocketing poverty challenges. The document further recognises that there is a considerable number of Basotho who are still unconvinced about the benefits of political democracy. They are also unclear about the existing constitutional endowments that defend their civil rights. According to the document, this unfortunate situation requires substantive democracy consolidation initiatives. One such intervention is an introduction of a civic education program in schools, anticipated to promote an understanding of democratic rights, responsibilities and procedures (International Monetary Fund 2006: xvi, 62).

It is patently established that citizenship education is needed for democratic stability in Lesotho. However, there is no direct allusion to how it could be properly introduced. The current article inevitably seeks to close this unfortunate omission. It proposes the teaching and learning of political citizenship through religious education. It consciously entered this critical discussion through a systematic literature review. A systematic literature review represents a scientific process of organising a body of literature relevant to the research question (Okoli 2015:43). The relevant literature was carefully collected through a computer search. The extensive search followed Egan et al.'s method (2001:5) of using single keywords. The fittingly single keywords included Lesotho's political democracy, citizenship education, religious education, secularisation, and postsecularism. In some specific cases, 'Boolean Operators' were sparingly used. Boolean Operators employ AND, OR and NOT commands to search for leading articles that combine information on the identified key concepts (Cronin, Ryan \& Coughlan 2008:40).

The conjunction $A N D$ was intentionally used to combine democratic citizenship education and religious education, post-secular and religious education, and religion and democracy. The classic literature review analysis method of the preview, question, read and summarise (PQRS) was appropriately used for a comprehensive analysis and a grand synthesis (Ramdhani, Ramdhani \& Amin 2014:52). The main research question that guided the objective criterion for intended inclusion and possible exclusion of priceless information from the vast literature was as follows: What is the rationale for integrating the citizenship education with religious education in Lesotho's secondary schools?

\section{Operationalisation of religious education and democratic citizenship education}

Religious education is a contested school subject. The debate centres primarily on distinguished models and aims of religious education. One prevailing model is conventionally referred to as the 'learning religion' model. The overriding aim of the 'learning religion' model is precisely faith formation. The model assumes a confessional approach, underpinned by 'teaching religion' or 'teaching for religion'. The practical purpose of this approach is to restore the faith of students belonging to the taught religious tradition. It also aims at converting the outsiders to the instructed faith. The evident intention is to explicitly impart religious beliefs, doctrine, identity, and promotion of ritual participative skills to the learners (Fabretti 2013:48-49; Hull 2002:5-7; Kuburi \& Moe 2006:3-6). The approach suffers from some educational defects. As its chief aim is to inculcate religious doctrines, it must opt for other forms of educationally questionable methods. It may carefully avoid or purposefully misplace relevant evidence that properly builds towards critical analysis of the fundamental doctrinal basis to realistically achieve its ultimate ends. It tends to reproduce students who are unable to assess religion through critical pedagogies. As a result, it fails to develop inquisitive, liberal minds relevant to the challenges of today's world. It intentionally suppresses potential crucial analytical skills to indoctrinate students into a specific religious tradition (Rauser 2009:78).

The second identified model is 'learning about religion', non-confessional approach, religious studies or religious knowledge. In this model, religion is taught and learned from the external perspective. 'Learning about religion' is succinctly defined as a 'scientific' study of religion. 'Scientific' study does not necessarily infer to the experimental analysis of religion, but to an 'objective', detailed and systematic study of religion. Objectivity, in this case, simply denotes an approach in which religion is studied without pre-existing religious assumptions. It implies a religious enquiry method of adopting a 'disinterested' observer stance. Disinterested does not necessarily refer to a state of being uninterested. 
It is essentially a position in which religion is studied as a way of life rather than as a mode of being (Felderhof 2008:4). At the core of the objective study of religion is precisely the deliberate avoidance of religious truth claims. This is done carefully to allow learners to enter the situation and experience religion in a broader sense. The 'Learning about religion' model is reasonably thought to properly promote religious tolerance and adequately prepare learners for a productive life in a multi-cultural or multi-religious society (Barnes 2002:71).

However, 'learning religion', or 'learning about religion' has some limitations. One serious problem identified is its emphasis on 'disinteresting'. Disinterested means 'epochê', disengagement or phenomenological bracketing of the emotional issues of religious truth. This methodical standpoint raises some questions when compared to the cognitive capabilities of both primary and secondary students. Secondly, avoiding students' religious experiences is invariably to deter them from the critical religious engagement. It fails them to carefully develop their own personal response to religious diversity and cultural uncertainty about religion. In this approach, students are properly guided to meaningfully engage with religious phenomena as cultural products of natural and human factors, without typically relating them to their faith experience. Such educational modes can only appeal to students' social and psychological proficiencies but negate their personal search for devout faith and spiritual development (Barnes 2002:73; Felderhof 2008:4).

The third archetypal model is popularly referred to as religious education or 'learning from religion'. In 'learning from religion' students are not taught as devout believers, while at the same time their religious experience and lifeworld are brought into focus (Hull 2002:7-8). 'Learning from religion' shifts the pimary aim of religious education from indoctrinating genres of 'learning religion,' and from the knowledge-based approach of 'learning about religion'. The focal point of 'learning from religion' is functionally to enable the learners to adequately develop religious awareness, reflexivity, and understanding of the self and others. In the 'learning from religion' perspective, the primary goal is to change the focus of religious education away from knowledge accumulation. The ultimate purpose is to enable learners to explore possibilities for active and dynamic personal identity formation processes. Accordingly, profound knowledge must be geared towards functional relation of the religious experiences of the learners (Wardekker \& Miedema 2001:85). Religious education becomes dialectic of 'learning religion' and 'learning about religion'. There is authentically a dialectic relationship between personal religious experiences, and objective received religious knowledge. In this sense, religious education operates efficiently within the constructivist theory. Constructivism accurately defines fundamental knowledge as socially constructed, socially related and socially eccentric relative rather than cognitive objective, fixed, and external to the learner's holistic views.
'Learning about religion' only provides scaffolding to facilitate the functional integration of 'received' religious knowledge into a personalised, constructed system of religious meanings (Engebretson 2008:3-4).

The operationalisation of religious education in this conceptual article is within the fundamental limits of the 'learning from religion' premises. The current religious education curriculum in Lesotho undoubtedly follows the 'learning religion' model. The model is basically Christian education based (Ministry of Education and Training 2014). Therefore, the current article does not simply propose an integration of citizenship education into existing religious education, but also a change of the approach in religious education. Religious education can contribute to the promotion of stable democracy only if religious knowledge and experiences are incorporated into the socio-political life of a learner.

Akin to religious education, citizenship education is also a disputed school subject. In the first place, democratic citizenship education has different nomenclatures including active citizenship, civic education, political education, citizenship education, citizenship learning, education for democratic citizenship, social education, human rights education, democracy learning, learning to live together, life skills and moral education, political socialisation and democratic education (Althof \& Berkowitz 2006:501; Cecchini 2004:3; Kerr 1999:2). In the second place, democratic citizenship can be taught and learned in formal and in nonformal education settings. There are also different approaches to school-based citizenship education. It can be taught and learned in the cross-curricular education system where related topics of political citizenship are incorporated in different subjects. It can also be integrated with separate subjects like social studies, geography, development studies and religious education. It can also be taught as a separate, stand-alone subject (Kerr 1999:13; UNESCO 2015:45-46).

In this conceptual article, the concept of citizenship education is not used as an ideal, but to distinguish it from other types of citizenship education in Lesotho. The first is life skills education. Life skills education covers a vast range of curricular themes including:

health promotion and disease prevention; environmental protection and disaster risk reduction (DRR); social and emotional learning and psychosocial support; human rights, active citizenship and social cohesion; and independent livelihoods and financial literacy within specific country contexts. (UNICEF 2012:7)

Life skills-based health education was introduced in Lesotho in 2007 and 2008 as a school-based sexuality and HIV prevention education. Its specific focus is undoubtedly on health and sexuality rather than political issues (Khau 2012:413; Kolosoa \& Makhakhane 2010:2). The second is civics education. Civics education in Lesotho is offered informally and periodically at election times. It is the ultimate 
responsibility of the Independent Electoral Commission (IEC) to efficiently deliver civics education for the general population. IEC works in mutual collaboration with other stakeholders such as non-governmental organisations (NGOs) political parties, and some appropriate government agencies. The methods used include the use of posters, national gatherings, radio programmes and newspapers (Ngozwana 2014:48). This periodical, informal civics education is also referred to as 'voter education'. It only prepares and encourages citizens to take part in democratic elections without necessarily imparting democratic values or encouraging participation in democratic rule beyond elections. This article sternly proposes an integrated citizenship education model, where citizenship themes are unified within religious education. The aim is to cultivate values of democracy, knowledge of representative rule and active participation of the citizens in democratic governance.

\section{The theoretical framework for the possible integration of democratic citizenship and religion education}

The proposed integration of citizenship education and religious education is carefully guided by the post-secular philosophical proposition. The preferential term post-secular according to Stoeckl (2011:1-4), should not be construed with de-secularisation or post-secularity. The two presuppose a regime-change that accommodates religion back in its rightful place of the civic role that had been appropriated by the secular forces. Instead, post-secular must be properly understood as the contemporary condition of pleasant coexistence between secular and religious epitomes. The term post-secular does not suggest a historic period of the returning of religion from where it had been pushed off for its apparent incompatibility with modernity. The logical interpretation of post-secular as a regime-change typically means that at some time in the past, there was a 'religion'. Its pillars of faith, beliefs, and rituals dominated human understanding with the mythical interpretation of the world. After religion, 'modernity', with its philosophical, meaningful secular views replaced religious beliefs. Now it is the time for the coming back of religion to reclaim its rightful place that was usurped by modernity. In this case, the 'return of religion' is understood as a direct attack of modernity that would be eventually replaced by religion. It is therefore proposed that post-secular be intentionally used without a hyphen. That is, not as post-secular because the post means after, plausibly suggesting after secular regime (Stoeckl 2011:1-4).

Post-secular, as Fabretti (2013:56-57) postulates, does not refer to the process of desecularisation. It instead refers to the recognition that there is increasing a dialectic relationship between religion and secular. This dialectic relationship, rather than promoting antagonistic perspectives, develops the distinct possibilities of mutual existence and borrowing between religious and secular viewpoints. In education, post-secular defines a constructive process of bringing together religious and secular themes in a dialogic manner.
Boeve (2012:144-145) is more specific in combining Christianity with post-secular. Boeve proposes that postsecular should be discussed together with post-Christian (even though Boeve's post-Christian is hyphenated, in keeping on with our compelling argument that hyphenated post- would mean 'after', unhyphenated post-Christian is invariably preferred). Artfully combined with postsecular, post-Christian is used strategically to indicate that Christian faith (in predominantly Christian societies like Basotho society) still maintains a remarkable position in civil societies and civic culture. It, however, defines people's collective and individual identity. However, it can no longer be regarded as an exclusive solution, sole provider, a satisfactory answer to all human problems and search for meaning in life. Nonetheless, it continues occupying a crucial position and plays a significant function in providing the needed answers to human questions. However, in a changed form that allows it to work diligently with other prevailing religions, human, social and political interpretations of the modern world (Boeve 2012:144-145).

In religious education, Fabretti (2013:56) satisfactorily explains that the combination of post-Christian and post-secular advances the following: (1) post-secular civil society remain increasingly a multi-religious society in which no one religion could legitimately claim exclusive monopoly of religious truth; (2) the realisation that living and practising religion (all religious traditions) cannot be typically restricted to private individuals' unique experiences, but manifests itself within collective and public life; (3) the recognition of coexistence between religious and non-religious in the public sphere as a 'space in common; (4) the necessary ability from both secular and religious actors to critically engage in dialogue and contentious exchange of reasonable ideals in civic life; and (5) the search for sacred spirituality transcends secular forces but manifests itself in public life (Fabretti 2013:56).

The practical approach to religious education that recognises both post-Christian and post-secular is 'learning from religion'. Fabretti (2013:54-56) eloquently explains that 'learning from religion' accurately provides interconnectivity between opposing religious and secular views. Rather than providing learners with religious neutral facts, 'learning from religion' properly prepares them to constructively develop personal orientation and cultural identity. It introduces learners to both religious communities and civic life. It carefully prepares learners to meaningfully participate in a plurality of religious communities and secularised contexts.

The balancing of 'learning from religion' and secular ideas within the post-secular theses, acceptably sets a key base for the successful integration of citizenship education and religious education.

\section{Lesotho's context}

There are basically two possible ways in which post-secular or post-Christian offers a consistent interface between religion and secular in the context of Lesotho. In the 
first place, it accurately explains the current state of notable secularisation affairs in Lesotho. In the second place, it offers a guide for the plan of moving to the front. In the context of Lesotho, post-secular or post-Christian explains that even though Lesotho has been exposed to secularisation, there was and is no clear demarcation between religion and secular. Casanova (2006:7) thoughtfully provides three fundamental categories on which secularisation could be carefully analysed. These are:

a. Secularization as the decline of religious beliefs and practices in modern societies,

b. Secularization as the privatisation of religion, often understood both as a general modern historical trend and as a normative condition, indeed as a pre-condition for modern liberal democratic politics, and

c. Secularization as the emancipation of the secular spheres (state, economy, and science). (p. 7)

The second component explains secularisation in Lesotho. Secularisation in Lesotho can be detected in the constitution. In pursuit of democratic principles of freedom and equality, the constitution of Lesotho states that:

Every religious community shall be entitled, at its own expense, to establish and maintain places of education and to manage any place of education which it wholly maintains; and no such community shall be prevented from providing religious instruction for persons of that community in the course of any education provided at any places of education which it wholly maintains or in the course of any education which it otherwise provides. (The Government of Lesotho 2008:15)

However, historical conditions have indisputably given the Christian religion an educational advantage over other religions. The first foreign religion to gain recognition in Lesotho in the 1830s was the Christian religion. Formal education was introduced by the Christian missionaries from the same period. Missionaries regarded Christian education as an essential ingredient for the propagation of the gospel. Schools were established alongside Christian churches. Gospel dissemination was essentially the gradual spread of formal education (Jobo et al. 2000:2-3; Matsoha 2010:3-4; Molelle 2006:5). At present, the Christian religion and education are dominant in Lesotho with an approximately $90 \%$ Christian population. About $80 \%$ of all primary and secondary schools are owned and operated by different Christian denominations. The Christian denominations that own schools include the Roman Catholic Church, the Lesotho Evangelical Church, the Anglican Church, and the Methodist Church. Without exception, church schools are offering mandatory religious education approved by the government (United States Department of State 2014:2). This means that learners from the minority $10 \%$ religious groups, including Muslims, Hindus, and Bahai are obliged to learn Christian education in a predominantly Christian education system. There are also some of the public schools in which Christian education is offered (United States Department of State 2014:2). The situation offers the learners from the minority religious groups a very little choice of non-Christian oriented education schools.
The minority religious groups are also adversely affected by the civil provisions of the constitution. Their religious liberty is infringed by the same freedom enshrined in the constitution. Protecting religious freedom of the minority religious groups, the constitution reads thus:

Except with his own consent (or, if he is a minor, the consent of his guardian), no person attending any place of education shall be required to receive religious instruction or to take part in or attend any religious ceremony or observance if that instruction, ceremony or observance relates to a religion other than his own. (Government of Lesotho 2008:15)

Without the availability of equitable religious education opportunities, minority religious groups enjoy limited religious freedom if any, in the school setting. Although the constitution granted the Christian church the freedom to teach its own religion, church schools and Christian education have not been denationalised. The Education Act 2010, classifies church schools as public schools. According to the Act, public schools are legally defined as schools:

1. Whose admission requirements comply with such public policy as determined by the Minister and are bound by Government rules and regulations;

2. Which are funded by the Government and charge such fees as approved by the Minister; and

3. Whose teachers are paid by the Government. (The Government of Lesotho 2010:170-171)

Church schools are wholly funded by the government. The fees in church schools are determined by the government, they abide by government education policy, and their teachers are paid by the government (Government of Lesotho 2005:131-132; The World Bank 2005:2, 24; UNESCO 2006). Christian education remains a statutory subject and falls within the national curriculum developed by the National Curriculum Development Centre (NCDC). The National Curriculum Development Centre represents a government body charged with curriculum development in mutual collaboration with other stakeholders including school proprietors (church officials) (The Government of Lesotho 2005:102-103).

Secularisation contradictions, in which there is an apparent separation as well as collaboration between religion and secularism underscores the actualities of post-secular theses. That is a dialectic relationship between 'religion' and 'secular' viewpoints. This dialectic relationship, rather than promoting antagonism, offers opportunities of coexistence and mutual sharing of standpoints. When each of the two tries to escape the other, it generates its own problems. Watson (2015:1459) meticulously maintains that in $g$ enhancing principles of democracy, secularisation violates the same principles it propagates. For example, democracy presupposes pluralism, and to privatise religion is essentially the exclusion of it from public plural life. The principle of toleration implies acceptance of conflicting views including religious perspectives. Constitutional freedom of speech must be 
granted in an exchange of opposing views for constructive debates between religious and non-religious positions. Openness to an enquiry in liberal education means investigating both religious and non-religious claims.

The limitations of secularisation equally affect the teaching and learning of religion. Privatised religious education inevitably tends to adopt a confessional or 'learning religion' approach. The problems of the confessional approach in the context of education have been discussed earlier. These problems unanimously affirm that religious citizens and secular actors should come together in a harmonious relationship for the social, moral and political betterment of all. This is precisely the exceptional opportunity seized by this article. This article thoughtfully proposes the effective integration of citizenship education and religious education for a sustainable democracy in Lesotho's context.

\section{The rationale for integrating citizenship and religious education in Lesotho's context}

There are different reasons motivating the necessary integration of religious and citizenship education in Lesotho's context. Firstly, the sheer fact that religion and secularity recognise democratic principles differently, provides a credible educational method to critically engage with the democratic processes. Critical thinking is supported worldwide (Aliakbari \& Faraji 2003; Bermudez 2015; Marginson 2006; Nagda, Gurin \& Lopez 2003) for its educational credibility, particularly when applied in relation to informed participation in the democratic system. According to Bermudez (2015:103-104), critical thinking profitably employs unique tools of philosophical enquiry including problem-posing, reflective scepticism, multiperspective and systemic thinking. In the liaison between secular (citizenship) and religion, which equip learners with diverse viewpoints of democracy, multi-perspectives are incredibly important. These empower learners to engage in critical judgement and active practice assiduously. This also enable them to recognise that religion and secular grapple with democratic moral dilemmas and contested multiple issues cannot be simply comprehended by applying one's personal preferences, proclivities and traditional background. These moral dilemmas and controversies set a philosophical base for the reasonable dialogic approach of constructively engaging with diverse viewpoints to develop sensible judgements and select informed choices that fairly cherish the fundamental rights and the specific needs of others with diverse views (Bermudez 2015:103-104).

Secondly, there exist mutuality between religious and citizenship (secular) views of democracy. Although perspectives are diverse, a dialectic relationship means the difference in sameness or sameness in difference. In a published book, A plea for peace and prosperity: Vision, virtues necessary for the spiritual, political and economic development of Lesotho, Mashologu (2015:1-11) writes extensively to show that religion is undoubtedly a valuable benefit of democratic stability. Both local and universal religious traditions can extremely contribute to the promotion of democratic stability. Locally, there are invariably core values of Basotho Traditional Religion which have been accurately translated into the national motto which is khotso, pula and nala [peace, rain, and prosperity]. These three moral values emphasise the philosophical logic of a gracious life. Firstly, there should be the kindred spirit of genuine peace in which humans can only experience their human nature in harmonious relation to others motho ke motho ka batho' [a person can wholly remain a person in harmonious relations with others]. When the conforming spirit of genuine peace and botho [humanness] has been nurtured, the personal prosperity is inevitable. The supernatural power (Molimo) would be graciously pleased and adequately provide for natural necessities such as rain. Therefore, people should constantly work and strive for peace. All international religions including Baha'i, Christianity, Judaism, Islam, Buddhism and Hindu advocate for religious principles of democracy. These principles are compatible with the secular view of democracy. They include unity among humans, equality, protection of family sanctity and respecting life sanity, the balance of material and spiritual civilisation, divine economic development, peace and good governance (Mashologu 2015:7-20).

Thirdly, the dominance of the Christian church in Lesotho's education system in which the church operates $80 \%$ of primary and secondary schools and that almost all of them including some Government owned schools offer religious education (The World Bank 2005:31; United States Department of State 2014:3), means that if integrated into religious education, citizenship education is likely to spread easily and rapidly influences the most considerable number of Basotho people.

Lastly, Christian denominations that own schools had conventionally grouped themselves in an ecumenical organisation, Christian Council of Lesotho (CCL), constituted as early as 1965. CCL was typically formed on the fundamental basis of 'promoting Christian faith and serving as a prophetic voice in national unity and social development' (CCL 2014). The first on the official list of its specific programmes is 'Good governance and respect for human rights'. The programme covers various areas including conflict resolution, democracy education, human rights education, human rights protection, and peacebuilding. The broad objectives of the programme are organised under:

civic education on democracy and human rights; legal support to victims of human rights violations; dissemination of human rights information; civic education on conflict resolution and peace-making; and voter education and independent elections monitoring. The Program also aims to carefully coordinate the key role of the Church in Lesotho in helping to resolve political upheaval. (CCL 2014)

This is assuredly a favourable indication that the church had for a long time felt mandated to lead in citizenship education. Teaching citizenship education through the 'learning from 
religion' approach positively enhances the CCL's prime purpose of promoting Christian faith alongside secular views. It responds to the church's responsibility of the promotion of democracy for national unity and development. Hull (1998:6) has emphatically stated that the presence of Christianity in education cannot be restricted to the teaching of Christianity but [enhances] multi-faith religious education. The ultimate motive for its active involvement in education is not to pursue the selfish propagation of Christian faith, but to provide credible education services to the people.

\section{Conclusion}

Integrating citizenship education in religious education is likely to contribute positively to the successful promotion of the highly anticipated democratic stability in Lesotho. It may not be as prompt as the national Vision 2020 had projected. The ambitious national Vision 2020 document was carefully compiled through a participatory approach from the National dialogue in 2000 and it envisaged that:

By the year 2020, Lesotho shall be a stable democracy where the principles of good governance will be anchored on the respect for human rights, the rule of law, political openness, political participation, and tolerance. This form of governance will be based on five pillars of democracy that encompass: the supremacy of the will of people, transparency, a devoted and efficient public service, justice for all and efficient chieftainship. (Central Bank of Lesotho 2004)

The timeframe of the national Vision, ambitiously set for 2020, indicates how much the Basotho long for an immediate stable democratic rule. The proposed education intervention may not bring about instant, but rather permanent largescale results. There is undoubtedly ample literature properly supporting the essentiality of citizenship education for the gradual strengthening of democratic governance. For example, Print and Lange (2012:2) elucidate that modern democracies in general, are burdened with various challenges including the inability to sustain themselves particularly in times of crises. Among many specific strategies that could be used appropriately to sustain genuine democracy; education intervention can colossally contribute to the development of active, informed citizens who will demonstrate the capacity to maintain democracy. Levinson (2011:6) accedes that many countries are assessed with unprecedented challenges including divided citizenry, and the overwhelming influence of money in politics. These challenges hinder governments to faithfully serve its citizens for the common good. The system of democracy which ought to address these challenges seems to fall short. Agreeably there is no unique solution to consolidate democracy, but there is one vital solution, often overlooked by politicians, educators, and civic activists, and that is citizenship education. In support, Cecchini (2004:2) opines that the fragility of democracies legitimises the undeniable fact that living in a democracy is neither inborn nor to be naturally taken for granted. Democratic culture, just like any culture, is made up of universal values and standard rules of society which need to be transmitted and learned. Citizenship learning is therefore inevitable for democratic systems.
These prevailing views promptly bring to light the indisputable fact that democracy is uniquely a fragile system of governance. This is especially true for the countries in which there has never been a time of stability like Lesotho. It is therefore imperative that continuous mechanisms are put in place to ensure its sustainability. Democratic principles and processes should be implanted in the social fabric so that they instantly become the culture of the people. In this respect, religion combined with citizenship education becomes fundamentally necessary to develop a democratic culture. That culture should represent the spirit, willingness and ability to engage in the promotion and maintenance of democratic sustainability. Through the extensive analysis of Walzer (1995) and Perry (2002), writings on the fundamental value of religious education for citizenship, prudently gathered that, as indicated by Kunzman (2005):

We probably need reminding that, at its best, religious discourse in public culture is not less dialogic - not less open-minded, not less deliberative - than is, at its best, secular discourse in public culture. The problem, of course, is that public religious discourse is rarely at its best; but the blame for this shortcoming can hardly be placed only at the feet of the religious. An increasingly diverse society should not lead citizens to shy away from the in-depth exploration of and deliberation about their moral convictions, whether influenced by religion or not. Rather, the need to engage and respect this diversity demands that schools prepare citizens to do this. But to expect this respectful engagement by citizens who have not had the opportunity to develop these skills in the public education realm seems unrealistic. Democracy is still, always, a politics of strain ... That is why education is so important - school learning (also practical experience) aimed at producing the patience, stamina, tolerance, and receptiveness without which the strain will not be understood or accepted. Inviting religion into the civic conversation is a daunting challenge, but one worth the strain. (pp. 167-168)

Banks (2017:372) conveys evidence-based information that it is difficult for students from cultural, ethnic, linguistic, and religiously diverse communities to comprehend citizenship education that does not reflect key elements of their cultural background. Based precisely on the citizenship education theory and scholarly research, structural inclusion through religious and cultural recognition is crucial to enable individuals to internalise democratic culture. It facilitates active participation in political decision making. Brandt and Böwadt (2009:33) reason that the successful integration of citizenship education with education in religion considerably helps the students participate in the discussions about religion in the public sphere. It also promotes political virtues of tolerance, respect and peaceful living together with religious 'others'. In the agreement, Banks (2004:292) maintains that citizenship education should help students to acquire the knowledge, attitudes, and skills needed to function in their nation-states. It should also enable them to function in a diverse society experiencing rapid globalisation and quests for ethnic, cultural, language, and religious groups for recognition and inclusion. Citizenship should also aid them to adequately develop a lifelong commitment to act and instantly transform the world to make it just. Miedema (2010:3-4) propounds that it is undoubtedly the ultimate responsibility of each government in liberal democratic 
societies to provide citizenship education. However, such education should convey the philosophical concept of 'inclusive education' seriously. That is the notable inclusion of multi-worldviews and religious traditions. It has to sufficiently take into account the political-pedagogical approach where the school becomes a place for pupils to be enabled to practice and interact with multiple perspectives. These perspectives include religious or worldviews and citizenship education. In this way, children are cordially prepared to confront situations in which religion exerts a direct influence in citizenry and polity.

\section{Acknowledgements \\ Competing interests}

The author declares that he has no financial or personal relationships which may have inappropriately influenced him in writing this article.

\section{References}

Akokpari, J., 1998, 'Democratic stability in Lesotho', Lesotho Social Science Review $4(2), 65-82$.

Aliakbari, M. \& Faraji, E., 2011, 'Basic principles of critical pedagogy', 2011 2nd International conference on humanities, historical and social sciences IPEDR vol. 17, pp. 77-85, viewed 15 March 2018, from www.ipedr.com/vol17/14CHHSS $\% 202011-\mathrm{H} 00057$

Althof, W. \& Berkowitz, M.W., 2006, 'Moral education and character education: Their relationship and roles in citizenship education', Journal of Moral Education 35(4), 495-518, viewed 25 March 2018, from https://www.researchgate.net/ publication $/ 248958610$

Banks, J.A., 2004, 'Teaching for social justice, diversity, and citizenship in a global world', The Educational Forum 68, 289-298, viewed 19 March 2018, from http:// depts.washington.edu/centerme/Fs04banks

Banks, J.A., 2017, 'Failed citizenship and transformative civic education', Educational Researcher 46(7), 366-377, viewed 19 March 2018, from http://journals.sagepub. com/doi/pdf/10.3102/0013189X17726741

Barnes, L.P., 2002, 'Christian confessionalism, and phenomenological religious education', Journal of Education \& Christian Belief 6(1), 61-77, viewed 17 May 2018, from http://citeseerx.ist.psu.edu/viewdoc

Bermudez, A., 2015, 'Four tools for critical inquiry in history, social studies, and civic education', Revista de Estudios Sociales 52, 102-118, viewed 18 May 2018, from http://www.scielo.org.co/pdf/res/n52/n52a08

Bertelsmann Stiftung's Transformation Index (BTI), 2016, 'Lesotho Country Report' Bertelsmann Stiftung, Gütersloh, pp. 1-43, viewed 25 October 2017, from http:// www.bti-project.org

Boeve, L., 2012, 'Religious education in a post-secular and post-Christian context' Journal of Beliefs \& Values 33(2), 143-156, viewed 20 March 2018, from https:// lirias2repo.kuleuven.be/bitstream/handle/123456789/369247/12.3.pdf;jsession id=1DFA03D4DCD1CD5D528BD3FA0755COFD? sequence $=1$

Brandt, A.K \& Böwadt, P.R., 2009, 'Citizenship education in denmark', in K, Sporre \& $\mathrm{G}$. Svedberg (eds.), Changing societies-values, religions, and education, pp. 24-35. Umeå School of Education, Umeå University.

Casanova, J., 2006, 'Rethinking secularization: A global comparative perspective', The Hedgehog Review 7-22, viewed 20 March 2018, from http://www.iasc-culture. org/THR/archives/AfterSecularization/8.12CCasanova.pdf

Cecchini, M., 2004, 'Education for democratic citizenship in Europe: Concepts and challenges for action', paper presented at networking European citizenship from http://e-learning.ngo.lv/wp-content/uploads/2012/04/Cecchini.pdf

Central Bank of Lesotho, 2004, 'Lesotho vision 2020: The way forward', Economic Review 1-4, viewed 15 March 2018, from https://www.centralbank.org.ls/index. php/research

Christian Council of Lesotho (CCL), 2014, The Christan Church of Lesotho, viewed 20 March 2018, from https://www.globalministries.org/africa/partners/christiancouncil-of-lesotho.htm

Cronin, P., Ryan, F. \& Coughlan, M., 2008, 'Undertaking a literature review: A step-bystep approach', British Journal of Nursing 17(1), 38-43, viewed 13 June 2016, from https://www.researchgate.net/publication/5454130

Egan, M., Petticrew, M., Ogilvie, M. \& Hamilton, V., 2001, Protocol for systematic review, viewed 18 May 2018, from http://web.ftvs.cuni.cz

Engebretson, K., 2008, 'Learning about and learning from religion: The pedagogical theory of Michael Grimmit', in M. de Souza, G. Durka, K. Engebretson, R. Jackson $\&$ A. Mcgrady (eds.), International handbook of the religious, moral and spiritual dimensions in education, pp. 667-678, Springer, London.
Fabretti, V., 2013, 'Learning from religions: Post-secular schools and the challenge of pluralism', Italian journal of sociology of education 5(2), 46-66, viewed 30 April pluralism', Italian journal of sociology of education 5(2), 46-66, viewed 30 April
2018, from http://ijse.padovauniversitypress.it/system/files/papers/2013_2_3.pdf

Felderhof, M., 2008, Religious instruction, religious studies, and religious education, pp. 1-6, viewed 03 January 2018, from https://www.faithmakesadifference.co.uk

Gay, J. \& Green, T., 2005, 'Citizen perceptions of democracy, governance, and political crisis in Lesotho', in M. Bratton, E. Gyimah-Boadi \& R. Mattes (eds.), A comparative series of national public attitude surveys on democracy, markets and civil society in Africa, pp. 1-27, The institute for democracy in South Africa (IDASA), Cape Town. (Afrobarometer, paper no. 13).

Government of Lesotho, 2005, Lesotho education sector strategic plan: 2005-2015, Government of Lesotho, Maseru.

Government of Lesotho, 2008, The Constitution of Lesotho, Government of Lesotho, Maseru.

Government of Lesotho, 2010, Education Act 2010 (Act No. 3 of 2010), Government of Lesotho, Maseru.

Hull, J.M., 1998, 'Utopian whispers: Moral, religious and spiritual values in schools', RMEP, Norwich.

Hull, J., 2002, 'The contribution of religious education to religious freedom: A global perspective', in T.M. Caldwell (ed.), Religious education in schools: Ideas and experiences from around the world, Proceedings of the UN's international conference on school education in relation with freedom of religion and belief, tolerance, and non-discrimination, held in Madrid, Spain, International Association for Religious Freedom, Oxford, 23-25 November 2001, pp. 4-11.

International Monetary Fund (IMF), 2006, Kingdom of Lesotho, poverty reduction strategy 2004/2005-2006/2007, International Monetary Fund, Washington, DC.

International Monetary Fund (IMF), 2012, Kingdom of Lesotho, national strategic development plan 2012/13-2016/17: Growth and development strategic framework, International Monetary Fund, Washington, DC.

Jobo, M., Khiba, R., Lefoka, P.J., Liphoto, N., Mapuru, P., Molise, M. et al., 2002, Lesotho: A baseline study of the teacher education system, University of Sussex Centre for International Education. (Multi-Site Teacher Education Research Project Muster).

Kerr, D., 1999, 'Citizenship education: An international comparison', pp. 1-31, viewed 28 April 2018, from http://www.seameo.orgrd

Khau, M., 2012, 'Sexuality education in rural Lesotho schools: Challenges and possibilities', Sex education: Sexuality, society and learning 12(4), 411-423, viewed 18 December 2017, from http://www.tandfonline.com/loi/csed20

Kolosoa, L.C. \& Makhakhane, B., 2010, 'Life skills for national development in Lesotho: Can ODL do it?' Pan-Commonwealth Forum 6 (PCF6) 249, 1-8, viewed 27 January 2017, from http://hdl.handle.net/11599/2259

Kuburić, Z. \& Moe, C., 2006, 'Introduction', in Z. Kuburić \& C. Moe (eds.), Religion and pluralism in education: Comparative approaches in the Western Balkans, pp. 1-8, CEIR, Novi Sad, viewed 28 April 2018, from http://www.theewc.org

Kunzman, R., 2005, 'Religion, politics and civic education', Journal of Philosophy of Education 39(1), 159-168, viewed 15 April 2018, from http://citeseerx.ist.psu. edu/viewdoc

Levinson, M., 2011, 'Benefits of civic education: Increased equality and narrowed civic empowerment gap', in J. Gould (ed.), Guardian of democracy: The civic mission of schools, Leonore Annenberg Institute for Civics of the Annenberg Public Policy Center, University of Pennsylvania, PA, viewed 17 May 2018, from http://nrs. harvard.edu/urn-3:HUL

Makoa, F.S., 2004, 'Electoral reform and political stability in Lesotho', African Journa on conflict resolution 4(2), 79-96, viewed 15 December 2017, from https://www. ajol.info/index.php/ajcr/article/view/39379/30304

Marginson, S., 2006, 'Engaging democratic education in the neoliberal age', Education Theory, 56(2), 205-219.

Mashologu, N., 2015, A plea for peace and prosperity: Vision, values and virtues necessary for the spiritual, political and economic development of Lesotho, Morija Printing Works, Morija.

Matsoha, F.M., 2010, 'Transforming society to meet the community needs and enhance the quality of life: A case study of Bishop Allard vocational school', MPhil thesis, Stellenbosch University.

Miedema, S., 2010, 'Maximal interreligious citizenship education', paper presented at the Religious Education Association (REA), conference, Denver, CO, 2-9th November.

Ministry of Education and Training (MoET), 2014, 'Lesotho general certificate of secondary education syllabus: Religious studies', National Curriculum Development Centre, Ministry of Education \& Training.

Molelle, K.H., 2006, 'Global policy discourse and local implementation dynamics: A case study of Lesotho's junior certificate religious and moral education syllabus', MA thesis, University of Cape Town.

Monyane, C., 2009, 'The kingdom of Lesotho: An assessment of problems in democratic consolidation', PhD thesis, Stellenbosch University.

Motsamai, D., 2015, 'Elections in a time of instability: Challenges for Lesotho beyond the 2015 poll', Southern Africa Report 3, 1-16, Institute for Security Studies, viewed 07 December 2017, from www.issafrica.org

Nagda, B.A, Gurin, P. \& Lopez, G.E., 2003, 'Transformative pedagogy for democracy and social justice', Race Ethnicity and Education 6(2), 165-191. https://doi. org/10.1080/13613320308199

Ngozwana, N., 2014, 'Understandings of democracy and citizenship in Lesotho: Implications for civic education', PhD thesis, University of KwaZulu-Natal. 
Okoli, C., 2015, 'A guide to conducting a standalone systematic literature review', Communications of the Association for Information Systems 37(43), 879-910, viewed 16 December 2017, from http://aisel.aisnet.org/cais

Perry, M.J., 2002, Love and power: The role of religion and morality in American politics, Oxford University Press, New York.

Print, M. \& Lange, D., 2012, 'Introduction', in M. Print \& D. Lange (eds.), Schools, curriculum and civic education for building democratic citizens, pp. 1-5, Sense Publishers, Rotterdam.

Ramdhani, A., Ramdhani, M.A. \& Amin, A.S., 2014, 'Writing a literature review research paper: A step-by-step approach', International Journal of Basic and Applied Science 3(1), 47-56, viewed 19 May 2018, from https://www.researchgate.net/ publication/311735510

Rauser, R., 2009, 'Learning in a time of (Cultural) war: Indoctrination in focus on the family's the truth project', Christian Scholar's Review, viewed 15 May 2018, from https://randalrauser.com/wp-content/uploads/2011/01/Learning-in-Wartime

Stoeckl, K., 2011, 'Defining the postsecular', paper presented at the seminar of Prof Khoruzhij, Academy of Sciences, Moscow, February 2011, viewed 20 May 2018, from http://synergia-isa.ru/wp-content/uploads/2012/02/stoeckl_en.pdf

Tsikoane, T., Tefetso H., Mothibe, T.H, Ntho, M.E. \& Maleleka, D., 2007, 'Consolidating democracy governance in Southern Africa: Lesotho', EISA Research Report 23(1-110), viewed 15 May 2018, from https://www.africaportal.org/documents/1845/rr32.pdf

United Nations Children's Fund (UNICEF), 2012, 'Global evaluation of life skills education programmes', Final Report, UNICEF, New York, viewed 25 April 2017 https://www.unicef.org
United States Department of State, 2014, 'Lesotho', International religious freedom report for 2014, Bureau of Democracy, Human Rights, and Labor, viewed 28 March 2018, from https://www.state.gov/documents/organization/238440

United Nations Educational, Scientific and Cultural Organization (UNESCO), 2006 'Lesotho', World Data on Education 6, 1-25, viewed 25 April 2017, from http:// www.ibe.unesco.org

United Nations Educational, Scientific and Cultural Organization (UNESCO), 2015, Global citizenship education: Topics and learning objectives, UNESCO, Paris.

Vhumbunu, C.H., 2015, 'Appraising the efficacy of SADC in resolving the 2014 Lesotho conflict: Progress and prospects', in V. Gounden (ed.), Conflict tends, the African centre for the constructive resolution of disputes (ACCORD), vol. 3, pp. 3-11, (ACCORD), Umhlanga Rocks.

Walzer, M., 1995, 'Education, democratic citizenship and multiculturalism', in Y. Tamir (ed.), Democratic education in a multicultural state, pp. 23-31, Blackwell, Oxford.

Wardekker, W.L. \& Miedema, S., 2001, 'Identity, cultural change, and religious education', British Journal of Religious Education 23(2), 76-87, viewed 17 March 2018, from http://www.informaworld.com/smpp/title ${ }^{\sim}$ content=t713616483

Watson, B., 2015, 'Can we move beyond the secular state?' Religions 6, 1457-1470, viewed 15 April 2018, from www.mdpi.com/journal/religions

World Bank, 2005, 'Primary and secondary education in Lesotho', Africa Region Human Development: A Country Status Report for Education, vol. 101, The Word Express, Netherlands, viewed 15 May 2018, from http://documents. worldbank.org 